\title{
Demand and supply planning in retail operations
}

\author{
Ferdoush Saleheen ${ }^{1}$, Md. Mamun Habib ${ }^{1}$, Bishwajit Banik Pathik ${ }^{2}$, Zurina Hanafi ${ }^{1}$ \\ ${ }^{1}$ School of Quantitative Sciences, Universiti Utara Malaysia (UUM), Kedah, Malaysia \\ ${ }^{2}$ Dept. of Electrical and Electronic Engineering, American International University-Bangladesh (AIUB), Bangladesh
}

\section{Email address:}

ferdoushsaleheen@gmail.com (F. Saleheen),md.mamun@uum.edu.my (Md. M. Habib), bishwajit.b.pathik@gmail.com (B. B. Pathik), h.zurina@uum.edu.my (Z. Hanafi)

\section{To cite this article:}

Ferdoush Saleheen, Md. Mamun Habib, Bishwajit Banik Pathik, Zurina Binti Hanafi. Demand and Supply Planning in Retail Operations. International Journal of Business and Economics Research. Special Issue: Supply Chain Management: Its Theory and Applications. Vol. 3, No. 6-1, 2014, pp. 51-56. doi: 10.11648/j.ijber.s.2014030601.18

\begin{abstract}
The research represents a comprehensive study of retail operation. The paper elaborates a broad perspective of a demand and supply chain which interacts with macro and micro environmental factors and translates it into a customer requirement. The authors describe on different techniques and tools on demand and supply planning which leads to an optimized level of inventory, less cash outflow, higher product varieties and a greater customer satisfaction. Eventually fulfilling all these ensures increase in sales and profits to stakeholders; an ultimate objective of a firm. This paper demonstrates a holistic view on how a firm's supply chain operates as a whole. In addition, this study also highlights some retail examples in the US as well as in Bangladesh which unlock further frontiers for the practitioners and prospective researchers to replenish their practices as well as expertise in the retail industry respectively.
\end{abstract}

Keywords: Vendor Managed Inventory (VMI), Electronic Data Interchange (EDI), Collaborative Planning, Forecasting and Replenishment (CPFR), Enterprise Resource Planning (ERP), Supply Chain, Demand \& Supply

\section{Introduction}

The borderless business competition in an uncertain and ever changing environment leads to an efficient and improved decision making practices in supply chain. Therefore when it comes to a business like retail that deals with one of most extreme uncertainties, manifold challenges, thousands of products on diverse categories; round the clock three-sixty-five day's operations require comprehensive and broader demand and supply planning. [1] It is taken almost granted that right product shall be available at a right price when a customer walks into a retail supermarket. [2] To meet the customer demand, retailers intend a broader range of product variety at a most competitive price; ensure sourcing efficiency at an optimum level, which ultimately gives higher profit to the company through vertical integration and efficient channel management. [3] According to Alexander H. Hibner, despite heavy investments in infrastructure and IT; retailers suffer a huge loss of sales opportunity as right products always could not be made available at a right time. The reason he identifies is due to lack of synchronization in demand and supply planning. In addition to this, continuous replenishment, merchandising planning, distribution lead time analysis, supplier delivery lead time, inventory holding period both at store and distribution center (DC), right order generation from store to distribution center (DC) and periodic on time delivery etc. are the prerequisites to ensure for the product availability and customer satisfaction in a retail. Therefore, [4] a synchronized demand and supply planning is essential to ensure thousands of individual decisions within supply chain to trigger in a real time environment.

\section{Literature Review}

To achieve a sustainable competitive advantage, a firm needs to have a business integration and visibility across the organization. [5] Enterprise Resource Planning (ERP) is a platform which spreads from supply chain, manufacturing, marketing, finance, human resource, and MIS etc. connected into a real environment and give every piece of transactions 
within figure tips. [6] According to Kahn and Mentzer, integrative activities in supply chain are defined as integration and collaboration, which exchange verbal as well as documented information. These activities should be tangible and be easily monitored. [7] Back in 1992, initiated by the fourteen trade associations including grocery manufacturers of America and food marketing institute formed "Efficient Consumer Response Movement" or ECR with an objective to practice supply chain business integration. [8] Based on the report of ERC movement by the aligned associations, which suggest that the maximum benefits of supply chain can be availed through four strategies: (i) efficient promotions; (ii) efficient replenishment; (iii) efficient store assortment and (iv) efficient product introductions. It also suggested to develop a trust based strategic information platform between manufacturers and retailers which can bring optimum level of supply chain efficiency. The report also elaborates the benefit of ERC to collaborate supply chain integration among its partners. [9] Eventually a technique has been developed called Vendor Managed Inventory (VMI). Under this platform the supplier (manufacturer) manages the inventory level for the retailer and replenishes the inventory. VMI is the first trust based business links between suppliers and customers. The concept has been first applied by the world's largest retailer Wal-Mart in the United States and Proctor \& Gamble. This results a great revolution to the grocery industries. Neil Tall Associates further stretched that the concept of continuous replenishment (CR) evolved as a business practice which involved the forecasting process through POS (Point of Sales) data in a real time environment. [10] Collaborative planning, forecasting, and replenishment (CPFR) also emerged in retail sector to improve the stock availability and reduce lead time and Wal-Mart being one of the first movers to implement the concept in the industry.

\section{Methodology}

The research represents based on the primary and secondary data includes interview with retail industry experts, online databases, books, journals, conference papers etc. Widespread research papers and conference papers have been appraised from International Journals such as PROQUEST, EMERALD, EBSCO, IEEE, ACM JSTOR etc.

\section{Discussions}

\subsection{Decision on Efficient or Responsive Supply Chain}

[11] To maximize the organizational efficiency, a firm should require supply chain and its operational principle in practice. As of today, among all the successful and big corporations including retail, supply chain efficiency has become a dominant corporate paradigm. This drives a firm to ensure a sustainable competitive advantage and to achieve higher profit and cost optimization. [12] Waller emphasizes effective supply chain as a pre-condition for a greater customer satisfaction in a firm through reducing cost. Therefore, he stretches "customer driven logistics", a concept which gained much popularity especially in retail to knot the loyalty of the end customers and the products. As an operational competency firms do consider price, quality, speed, reliability, dependability, flexibility and time. Thus, firms have been focusing more on a formula within a supply chain model to guarantee a value driven objective and a sustainability in the long term. [13] Fisher suggested formulating a supply chain strategy for a greater understanding of demand in a firm's products and services. He proposed a concept for two types of products either functional or innovative. The functional product category typically fast moving consumer goods such as "soup or bath soap" and the innovative category "Apple" computer or "highly perishable" products fits in. To elaborate it further functional products are widely available and cater a basic need. The demand cycle does not also change over time very frequent so the chance of demand predictability is higher. However, the customer price elasticity is high. For this type of products he proposed "Efficient" supply chain strategy which focuses more on cost optimization and price becomes key driving motivators to generate sales. He also mentions that, in an efficient supply chain, cost of production, transportation and inventory holding are minimized. On the contrary innovative products such as for "Apple" computer has shorter life cycle with volatile demand. Therefore demand predictability is difficult. The price elasticity level to customer is low and customer expectation is high. Therefore, this category of products should have "Responsive" supply chain strategy.

\subsection{Pull based Demand Approach}

On the contrary of Fisher [14] Holmstrom argued the urgency to understand the customer demand chain. He states that it is not adequate to focus only on "customer based logistics" to add value in retail. Logistics is only the process of transferring goods from the point of origin to the end customers. Therefore, to bring real value "Pull based demand approach" is critical and the concept of customer demand chain which transfers demand from market to suppliers. He further elaborated that demand of a retail firm consists of assortment planning in the outlet, decision on category management, inventory management policy; lead time assessment and finally the actual purchase. However, these two concepts "customer based logistics" and "pull based demand approach" brings together and form demand and supply chain. They are linked with order penetration point and the value offering point. In the order penetration point (OPP), the supplier allocates the goods ordered by the customer. And value offering point (VOP) occurs, where the demand and supply chain meets. He also referred an electronic application called Electronic Data Interchange (EDI). Through EDI both suppliers and retailers can have visibility of information. In this situation both the partners become beneficiary by reducing the cost and increasing the productivity while customers are benefitted from additional 
services that in turn lower their cost or perhaps add to their competitiveness.

\subsection{The process of Demand Chain}

[15] Demand chain management attempts to analyze and understand the overall demand for market within the firms current and potential product range. Supply chain by contrast emphasizes the efficiency in the production and logistics process; while the demand chain emphasizes the effectiveness of a business. Demand chain analyst helps to improve the organizations process by aligning the organization through a shared plan and improves coordination within the supply chain by using collaborative forecasts. [16] The following elements are to be considered while preparing a process of demand chain as follows:-

\subsection{Market Trend}

Macro Environmental Factors: The analysis explores business opportunities in retail and identifies products and market gaps. They thoroughly evaluate the current government import policies, duty structures, tax and supplementary duties while calculating the landing cost. The analysis identifies whether a customer can afford to purchase the product in comparison to other competitive brands. In addition to this, market segmentation is important at which market the firm intends to penetrate. Based on the segments on premium, upper or middle income group individual customer insight, buying habit, elasticity level, market trend, availability, demand and supply, potential competitor activity, product features, and benefits are studied holistically which translates the feasibility of the market size both in quantity and volume of business.

Micro Environmental Factors: The demand and supply planners try to identify the strength and weakness of the company and its product ranges. The firm expects a detailed quantitative analysis from the report generated in macro environment such as the average monthly basket size of a product or category, range of products that are usually captured in the basket, frequency of the consumptions, specific preferences, and flavors. The report also elaborates past sales for a particular product on SKU wise, Gross Profit (GP) \%; compare current and previous Trade and Maximum Retail Price (TP/MRP) which can influence the consumption level at a high or low. It also studies the substitute brands. In addition to this, the team has an ultimate goal to increase the profitability of the subcategory wise business sales. As such they decide which individual SKU (Stock Keeping Unit) can give the maximum $\mathrm{GP} \%$ and bring more traffic at outlet.

\subsection{Customer Profile}

Analyzing customer traits and sales trends based on geographic location are essential. The firms must have comprehensive list of products, called Master Category Data. Based on sales trend, demand, seasonality, and purchasing power; freezing level are done from the Master Category Data (MCD). The MCD also have ranking in terms of sales volume, quantity, GP\% contributions, percentage of contribution category wise. This analysis helps demand planners to use logic while calculating demand planning in regional and national level.

\subsection{Market Segmentation and Company Positioning}

[17] Each retail must have a unique selling proposition (USP) based on that they create a market position and capture market share. Such as Wal-Mart always focuses on price, however Whole Food focuses on "Organics" which makes them completely separate from the crowd. A customer who walks into Marks \& Spencer or Mecy's has a complete different mindset versus a customer who shops at TESCO which focuses on price and basic needs of the customers. Therefore, each retailer depending on the nature and their company's vision and mission develops a market positioning strategy that triggers and influences the demand and supply planning for that particular product.

\subsection{Product vs. Service Policy}

[18] Depending on the product type either functional or innovative, supply chain strategy is designed and distribution network is planned. If a firm plans to have an efficient supply chain focuses more on inventory reduction and cost optimization. Simultaneously, when a firm's strategy is on responsive operation, then it focuses on product availability with less priority on cost. Responsive supply chain comparatively has higher GP margin. Such as, when a customer walks into Gucci, Saks Fifth Avenue, or Armani outlet obviously expects a supreme customer service. Thus inventory holding is never a core concern, rather availability, product features and customer experience makes a difference. On the other side, retailers like TESCO, Sainsbury, and WalMart etc. which competes on low GP\% focuses on cost optimization, tradeoff between customer satisfactions with return on investments. Therefore, they focus on Pareto analysis. Inventory vs. Sales and dead stock mobilization from outlet is one of core jobs, so the company can reduce cash outflow and payment burdens.

\subsection{Category Management and Master Category Planning}

[19] On an average a supermarket carries (25,000 $35,000)$ products and a hypermarket carries from $(45,000-$ 65,000) Stock Keeping Units (SKU). A list of Master Category Data (MCD) which a retail carries in the outlet shows its GP\% SKU wise; category and sub category wise freezing level; percentage of shelf space on each category based on sales contribution; percentage of per square foot sales on each category; average basket size of customers; estimated list of products; competitors category analysis; planned GP\% margin growth; possible options to increase visibility of products; trends and current product penetration rate; year to year product and subcategory sales trends; fill rate analysis from outlet to distribution center etc. are all studied very methodically. Different supply chain parameters such as supply chain cycle time; vendor 
delivery lead time; supplier compliance level are also analyzed to give a comprehensive planning for the continuous growth of a firm. In recent trends, all major supermarkets now have full range of private labels as a substitute of leading brands. Firms like TESCO, Wal-Mart, and Safeway have private labels from cosmetics, toiletries, frozen food, dairy \& beverage etc. This gives a firm strong advantage to compete against price and divert traffic when the market is highly elastic. Reducing inventory holding days is one of major KPI's (Key Performance Indicators) of a demand and supply planner. Simultaneously they also focus on efficient handling of product distribution

\subsection{Inventory Policy}

[20] Careful planning on inventory level and its optimization is on the top priority for demand and supply planners. Firm's as a whole can be affected if inventory level is not properly maintained. It directly impacts on the cash flow of a company and hits the financial bottom-line. Too much inventory does not necessarily mean product availability and customer satisfaction rather it can jeopardize the company's profitability, as return on investment can be affected. Higher level of inventory also causes a big threat for a firm if products have shelf expiry date. Therefore, top management always has great concern for effective inventory management.

Depending on the nature of the business, expected service level, and sourcing lead time, inventory policy is made and it varies company to company. In addition to this lead time calculations from distribution center to outlet and supplier to warehouse are also considered along with multifold algorithmic calculations such Economic Order Quantity, Reorder Point, Re-order Quantity. And an "Auto Replenishment" formula is set in the outlet level based on all these factors which ensures that shelves are never empty and periodic replenishment is done.

\subsection{Outlet Merchandising \& Replenishment Planning}

[21] Outlet merchandising plan is done either through an advanced automated software platform called "Planogram" which gives the highest level of visibility of a particular product in selected categories. In addition to this, through permutation and combination it also gives an algorithmic analysis based on the sales of different categories which product should get at what percentage of shelf space. This also considers GP\% of all the product ranges. The demand and supply planners have their own Key Performance Indicators (KPI) and quarterly business target on category to category. Based on the target they can change the display merchandising, give the shelf space higher or lower as well as breadth and width. The merchandising has also different level of analysis targeting for different age groups such as keeping the sugar candy, chocolates, and breakfast cereals in the eye level. Most fast moving products are displayed in the eye level. Generally milk, dairy and frozen and necessary items are kept at the back of the outlet, thus customers need to travel to the supermarket. Fresh fruits and green vegetables are usually kept at the beginning which gives a fresh look and good feeling to the customers when they walk into the store. The bakery and deli items are put in such as place which can give aroma throughout the store and creates an appetite. The outlet merchandising is the first step where the demand and supply planning starts. In the outlet, the decision has to be taken how many pieces each SKU are to be kept such as it can be broken in size from $6,8,12$ pieces or cartoon size or multiple cartoons depending on the sales volume of the outlet. The merchandising quantity at shelf ideally should never run out of stocks and it is supposed to be remaining in the store and replenish after a certain interval. Simultaneously back store should also keep buffer stocks. Once the shelf gets empty, products shall be replenished from the back store promptly. An algorithmic calculation is done based on the number of pieces are to be kept in the shelf, and no. of pieces at back store depending on the lead time to replenish from distribution center to outlet. It is in fact a chain of cycle, as distribution center orders to warehouse and warehouse to procurement and procurement to manufacturers.

\section{The Process of Supply Chain}

\subsection{Warehouse Operations}

[22] In a fast paced competitive environment warehouse requires continuous improvement in design; particularly facilities in layout planning and distribution network design to bring higher efficiency in performance. To incorporate modern concepts such as Just-In-Time (JIT) or lean management brings new challenges to industry experts to rethink on several issues such as reduce inventory level, reduce lead time, minimize response time, and increase higher level of productivity. In less than a decade, the global retail industry has witnessed a significant achievements such as bar coding, Radio Frequency Identification (RFID), Enterprise Resource Planning (ERP) and Warehouse Management System (WMS) etc. Implementation of all these technologies contributes a real time environment of warehouse operation and faster communication with other supply chain partners. Many resources are involved in planning and operating of such warehouse like space, labor, and equipment in order to achieve capacity, throughput and service at a minimum cost. Grocery supermarket warehouse operation is complex. And it operates in an extreme uncertain environment. In terms of stock keeping unit (SKU), on an average a supermarket warehouse carries $(8,000$ $10,000)$ products.

\subsection{Warehouse Structure}

Warehouse Structure: [23] To ensure the highest level of operational efficiency, conceptual design and facility layout planning are crucial. Facility layout planning deals with functional issues such as storage capacities in particular departments, technological facilities which are required to deliver an optimal level of service on how orders shall be 
placed and executed. At this level, throughput requirement is one of the main concerns to serve storage facilities and future operating cost. Size and Dimension: Considers the construction cost of a warehouse, inventory holding policy, auto replenishment process and overall material handling procedures. To be specific, idea formulation is required on storage capacity of a warehouse under two circumstances (i) to determine inventory levels externally as the warehouse has no direct control of inbound shipments and (ii) under the circumstances when a warehouse can directly control the inventory policy. The objective of planning and process is to ensure the best system performance by allocating the appropriate space and achieve an optimum level of efficiency.

\subsection{Purchase Order}

The procurement department consists of members specialized in sourcing of multiple categories. At Meena Bazar (8-10) categories with $(8000-10,000)$ SKUs are sold such as (i) Grocery (Food and Non Food), (ii) House Hold, (iii) Apparel \& Linen, (iv) General Merchandise (including Personal Care), (v) Dairy \& Frozen, (vi) Produce (Fish, Meat and Vegetable), (vii) Stationary \& Toys, (viii) Tobacco and others. For each category and subcategories they have a specialized team which handles thousands of SKU's. In general a country like Bangladesh a procurement department handles from 1000-1500 suppliers. Companies like Wal-Mart, TESCO in global platform which carries from $(45,000$ $60,000)$ products need to handle from (3000-5000) global suppliers. Based on the demand and supply planning they need to raise purchase order. In an ideal environment Enterprise Resource Planning (ERP) with a module called Material Management (MM) which is universally popular handles these complicated tasks. However, all modern supermarkets now have advanced EDI (Electronic Data Interchange), VMI (Vendor Managed Inventory) systems. These are software applications where the ERP of the supplier is connected with the ERP of the retailer. This is a real time environment where sales, inventory position and forecast are shared. The objective of all these is to handle the uncertainty and availability of products jointly. Collaborative Planning, Forecasting and Replenishment (CPFR); a concept adopted by the retailers to reduce the bullwhip effect and ensure optimum inventory at all levels.

\section{Conclusion}

The paper thoroughly explained the practical as well as the theoretical approach of demand and supply planning in retail operations both in global and regional perspective. The authors also demonstrated on many principles such as (a) Enterprise Resource Planning (ERP); (b) Efficient Consumer Response Movement" or ECR; (c) VMI (Vendor Managed Inventory); (d) Collaborative Planning, Forecasting and Replenishment (CPFR); (e) Electronic Data Interchange (EDI), (f) Continuous Replenishment (CR) etc. which have been successfully implemented and brought outputs in the global retail organizations like Wal-Mart, TESCO etc. Simultaneously the authors discussed on the practical examples on Meena Bazar, a retail chain in Bangladesh. All these theories and practices give us a holistic overview to develop a demand and supply chain planning matrix. The grocery retail operation requires a hierarchical and sequential aspect of decision making that is why an advanced decision support system platform is essential. Retail is considered as one of most dynamic industries, where uncertainties, multifold challenges and constrains come altogether and the performance is evaluated by the customers on the supply availability with no compromise on price, quality and service. Therefore, optimizing inventory management, careful demand and supply analysis, integrating supplier and allocating of resources in Just-in-Time (JIT) environment give better performance. In this borderless business global competition, firms compete on multifold challenges and limitations. As the supply is greater than the demand, therefore it has been extremely difficult for a new entry player to survive. Not only that, even for an existing firm is has become extremely competitive to sustain. To ensure sustainable competitive advantage, a firm must focus on its demand and supply planning more on a collaborative approach, where visibility and real time information sharing with its partners can only ensure optimization of its resources and greater availability of its product.

\section{References}

[1] Saleheen, F., Miraz, M., Habib, Dr. Md. Mamun., Hanafi, Dr. Zurina., "Challenges of Warehouse Operations: A Case Study in Retail Supermarket", International Journal of Supply Chain Management (IJSCM), 2014 "In Print", Vol.3, No.4, ISSN 2050-7399, 01 .

[2] Hubner, A., Kuhn, H. and Sternbeck, M., "Demand and supply chain planning in grocery retail: an operations planning framework", International Journal of Retail \& Distribution Management, 2013, Vol. 41 Iss 7 pp. $512-530$.

[3] Hu“bner, A. (2011), Retail Category Management. Decision Support Systems for Assortment, Shelf Space, Inventory and Price Planning, Springer, Berlin

[4] Hu"bner, A. and Kuhn, H., "Retail category management: state-of-the-art review of quantitative research and software applications in assortment and shelf space planning", Omega, 2012, Vol. 40, No. 2, pp. 199-209

[5] Nakano, M., "Collaborative forecasting and planning in supply chains: The impact on performance in Japanese Manufacturers", International Journal of Physical Distribution \& Logistics Management, 2009, Vol. 39 Iss 2 pp. $84-105$.

[6] Kahn, K.B. and Mentzer, J.T. (1996), "Logistics and interdepartmental integration", International Journal of Physical Distribution \& Logistics Management, Vol. 26 No. 8, pp. 6-14.

[7] Robins, G. (1994), "Sailing into ECR's unchartered waters", Stores, Vol. 76, No. 10, pp. 43-4. 
[8] Bowersox, D.J., Closs, D.J. and Stank, T.P. (1999), 21st Century Logistics: Making Supply Chain Integration a Reality, Council of Logistics Management, Oak Brook, IL.

[9] Barratt, M. and Oliveira, A.,"Exploring the experiences of collaborative planning initiatives", International Journal of Physical Distribution \& Logistics Management (IJPDLM), 2001, Vol.31, No.4, pp.266-289.

[10] Blair, N.,"Minding the store: with inventory reduction measures under way in the warehouse, executives are eyeing similar strategies based on store-level", Supermarket News, 1998, 19 January, Vol.48, No.3,pp.81-2.

[11] Waller, A., "The globalisation of business: the role of supply chain management", 1998, Management Focus, No. 11.

[12] Rainbird, M., "Demand and supply chains: the value catalyst", International Journal of Physical Distribution \& Logistics Management (IJPDLM), 2004, Vol 34, ISS 3 / 4 pp. 230-250.

[13] Martin Christopher, Helen Peck, Denis Towill, "A taxonomy for selecting global supply chain strategies",The International Journal of Logistics Management, 2006, Vol. 17 Iss: 2, pp.277 -287 .

[14] Fisher, M.L. (1997), "What is the right supply chain for your product", Harvard Business Review, March/April, pp. 105-16.

[15] Hammer, M. (2001), The Agenda, Crown Publishing Group, New York, NY.

[16] MacMillan, I.C. and McGrath, R.G. (1997), "Discovering new points of differentiation", Harvard Business Review, Vol. 75, July/August, p. 133.
[17] Cao, Lan L. and Marc Dupuis (2009), "Core Competences, Strategy and Performance: The Case of International Retailers in China," International Review of Retail, Distribution and Consumer Research, 19 (4), 349-69.

[18] Swoboda, B, "Transferring the Retail Format Successfully into Foreign Countries", Journal of International Marketing, American Marketing Association, 2013, Vol. 21, No. 1, 2013, pp. 81-109

[19] James W. Hamister, "Supply chain management practices in small retailers", International Journal of Retail \& Distribution Management, 2012, Vol. 40, Iss : 6 pp. 427 - 450.

[20] Abd El-Aal, M., El-Sharief, M., Ezz El-Deen, A. and Nasser, A.; "A Framework for Evaluating And Comparing Inventory Control Policies In Supply Chains", Journal of Engineering Sciences, Assiut University, March 2010, Vol. 38, No. 2, pp. 449-465.

[21] Gooner, R.A., Morgan, N.A. and Perreault, W.D. (2011), "Is retail category management worth the effort (and does a category captain help or hinder)?", Journal of Marketing, Vol. 75 , pp. 18-33.

[22] Sussams, J.,"The Impact of Logistics on Retailing and Physical Distribution", Logistics Information Management, Vol. 7 Iss 1 pp. $36-40$.

[23] Jinxiang Gu, Marc Goetschalckx, Leon F. McGinnis (2007), Research on warehouse operation: A comprehensive review, European Journal of Operational Research, volume 177, 1-21. 